\title{
Improving Performance of Indonesia State-Owned Enterprises Holding; Policies and Strategies
}

\author{
Bambang Utoyo*, Marimin, Idqan Fahmi, Agung Primanto Murdanoto \\ IPB Business School, SB-IPB Building, \\ IPB Campus Gunung Gede, \\ Pajajaran Street (Bogor, Indonesia) \\ *Corresponding author's email: butoyo312 [AT] gmail.com
}

\begin{abstract}
The government has issued several policies to improve the performance of State Owned-Enterprises (SOEs), namely by establishing ABC SOEs or BUMN Holding, providing additional capital, guaranteeing the purchase of ABC SOEs products such as bio ethanol and bio diesel to be purchased by PT Pertamina, excess electricity supply from the sugar mills to be purchased by PT PLN. Meanwhile, ABC SOEs Holding has also implemented a strategy to improve the performance of $A B C$ SOEs Holding and its subsidiaries. Unfortunately, the implementation of those policies and strategies have not been able to improve ABC SOEs Holding performance as expected. We use Soft System Methodology (SSM) as frame work, which is combined with the strategic assumption surfacing and testing (SAST) and interpretive structural modeling (ISM). This study concludes that actions must be taken to improve the performance of ABC SOEs Holding: 1) strengthening of definite legal rules related to SOEs, 2) handling negative issues of plantation products, 3) synergy of holding and subsidiary decision making, 4) independent assessment of holding's performance, 5) strengthening subsidiary governance, 6) increasing capability and integrity of human resources, 7) strengthening technological development for production and distribution efficiency, and 8) developing talent pool for innovation improvement.
\end{abstract}

Keywords - Agroindustry, Holding, Performance Improvement, Soft Systems

\section{INTRODUCTION}

Corporate governance, accounting and accountability of SOEs are crucial and growing topics in public management and other research disciplines. [1] stated that public service provision and budget consolidation cannot be realized effectively and efficiently without powerful governance and management of SOEs. [2] notion that SOE-oriented corporate governance research is a growing field with wide-ranging opportunities for investigation. [3] notion that in order to regulate SOEs sensibly, five main elements must be reflected in the provisions: 1) a clear definition and well-defined scope; 2 ) clear general obligations and rights; 3 ) specific disciplines on trade-distortive practices by SOEs and specific exceptions; 4) provisions to improve transparency; and 5) rules regarding enforceability and dispute settlement.

SOEs are regional or national companies that are fully controlled by the state through majority or not majority but significant ownership defined by [4]. Per [5], State-Owned Enterprise (BUMN) is a business entity of which capital is entirely or partially owned by the state through direct participation derived from separated state assets. Meanwhile, [6] and [7] stated that State-Owned Enterprises in Kenya are semi-autonomous companies established by the government through the Law or Parliament. The main shareholder of BUMN is the government. The board of directors' report is submitted to the Government Minister under the portfolio. [4] stated that in Europe the state electricity and water companies can provide cheaper prices than the private sector.

Meanwhile, [8] mentioned that BUMNs have been considered unfavorable due to poor management, substantial amount of political influence, and unclear regulations. In addition, deviation from policy direction, high political costs that are difficult to measure, over-investment and squander, the availability of facilities from the state in the form of a subsidy which is equal to the cost suffered by people at large, insensitivity to the business environment, and company's tendency of being uncompetitive, late to act, and slow to make decisions also contribute to the unfavorable condition of BUMNs as concluded by [9]. [10] stated that BUMNs are difficult to manage independently if subsidized program and additional capital are provided by the government every year. [11] stated that the performance of Chechnya's BUMNs continues to dwindle and even reached a negative point because of heavy bureaucracy and the absence of a clear direction from the company. [12] stated South Korean firms have been influenced by the obstacle elements of the social-cultural environment more than those of political-legal ones. Several factors such as 'inconsistent application of law', and 'corruption of public officials', etc, are regarded as the obstacle elements of the political-legal environment. 
The government's efforts to improve the performance of BUMNs include establishing a holding for BUMNs that are similar in their business fields. The establishment of the holding company has been carried out in several business fields. The holding includes PT Pupuk Indonesia Holding Company for state-owned companies in the fertilizer industry, PT Semen Indonesia Holding Company for state-owned companies in the cement industry, and PT Rajawali Nusantara Indonesia Holding Company in plantation and pharmaceutical businesses, and ABC BUMN Holding for BUMN in the plantation business. Following the establishment of PT Semen Indonesia Holding Company and PT Pupuk Indonesia Holding Company, both companies showed significant improvement in their financial performance and production capacity [13].

The advantages of establishing a Holding Company are the diversification of investment risks from capital owners, reducing capital investment, and increased negotiation positions from holding as proposed by [14]. The size of the company is considered as a key factor in business prosperity. Companies with large capital and high market share have better access to supplier and sales networks by increasing bargaining power with suppliers and consumers. Another advantage of companies that have a strong position is their ability in creating an entry barrier for competitors in the market as stated by [15]. However, merging or fusing companies does not always yield the best results. [16] study showed that the failure percentage of merging or fusing companies is relatively large, and in the long run is close to $50 \%$.

Government policies and strategies built by ABC BUMN Holding to improve their performance have not been successful. In the holding establishment proposal, ABC BUMN Holding is expected to earn 11.27 trillion in profits in 2017. Unfortunately, in 2015, 2016, and the first semester of 2018 ABC BUMN Holdings still suffered losses.

\section{PROBLEM AND PURPOSE OF RESEARCH}

The government has issued a number of policies to improve the performance of ABC BUMN which include establishing a holding company, providing additional capital, guaranteeing ABC BUMN products such as bio ethanol to be purchased by PT Pertamina, and guaranteeing the electricity supply from the sugar factory will be purchased by PT PLN. ABC BUMN Holding also implemented strategies to improve its performance and its subsidiaries, among others, by restructuring subsidiaries debt, revitalizing sugar factories, reducing the number of human resources, and centralizing fertilizer purchases by the second semester of 2017. The policies and strategies that have been built have not been able to improve ABC BUMN Holding's performance as expected. The purpose of this study is to formulate policies that need to be carried out by the government and strategy that needs to be done by ABC BUMN Holding, to improve the performance of ABC BUMN Holding.

\section{LITERATURE REVIEW}

[17] stated that in the context of BUMN development, the government is expected to put forward three main principles for BUMN governance to be carried out properly, namely clear objective (clear mandate for BUMN managers so that they are only responsible to one party and clarity of company objectives whether it is commercial or social), transparency (the principle of high disclosure for both the government and state-owned enterprises), and political isolation (the government's duty is limited to being supervisors and directors, while managers are carried out by professional independently). [18] stated that several studies revealed reasons for maintaining State-Owned Enterprises (SOEs) in a country's economy. The Chinese government SOE restructuring program to increase its SOE's role and performance are triggered, among others, by natural monopoly for businesses that are not feasible for private companies, social reasons or development goals, investment benefits to assist the state budget, and the country's economic security. [19] stated that functionally, SOEs and large private companies in China have many treatment similarities from the State such as market access, state subsidies, proximity to state's power, and implementation of government policies. Thus, the boundaries between SOEs and Public Owned Enterprises (POE) in China are blurred. [20] stated that the government may have a goal that is contrary to the objectives of the SOEs and the management of SOEs must choose to follow it. In addition, the government's interests may not be the same as commercial interests, so the supervision of SOEs by the government becomes ineffective. The ineffectiveness of supervision carried out by the government resulted in the existence of several different government institutions that supervised SOEs.

[21] stated that strategy is planning and action to achieve organizational goals. Strategy bridges the gap between policy and tactics. Strategies and tactics bridge the distance between efforts (means) and the final goal (end). Strategy is related to efforts. Strategy relates to how to achieve goals, not goal specifications. Strategy is one of the four structural elements. First, is the goal to be obtained, second, is the strategy to achieve a goal or the way resources are deployed, third is the tactics or how the resources that have been deployed are used, and fourth is the resources themselves, in other words, the efforts that we have. Strategies and tactics bridge the distance between effort and goal. [22] interpreted strategy as a framework that guides their choices in determining the nature and direction of the organization. In the end the strategy boils down to the choice of products or services that will be marketed. Company leaders are the main drivers of business. Although there are nine driving forces, only one can be the basis of business strategy. Nine possible business drivers are products offered, market needs, technology, production capacity, sales methods, distribution methods, natural resources, size and growth, and return or profit. 
In developing a holding strategy, holding management should pay attention to the added value that can be given to subsidiaries, namely service unity, sales between units, economies of scale, sharing resources, multi competence, vertical integration, sharing knowledge, new business development, and risk management [23]. [13] stated that the success in establishing a state-owned cement and fertilizer holding company was also influenced by the strategies implemented by the holding company. The strategies include integrating the marketing system of all subsidiaries, integrating policy-making functions, integrating procurement functions, integrating financial functions including financing, and integrating investment functions. [24] stated the organization must consider that employees are very vital in carrying out a change process. Sustainable long-term success and performance of the organization depends on employees.

\section{RESEARCH METHOD}

This study is conducted using the SSM as framework approach [25]. Specific systems are derived after getting results from SSM in the form of a Purposive Activity Model (PAM) as material for structured debate processes, subsequently the SAST and the ISM method is employed. The same method is also used by [26]. [27] stated that with a system approach, factors that influence the behaviour and success of an organization are revealed. In the SSM, problem solving is done using 7 (seven) interrelated stages that show clear coherence [28]. The stages of the research are shown in Figure 1.

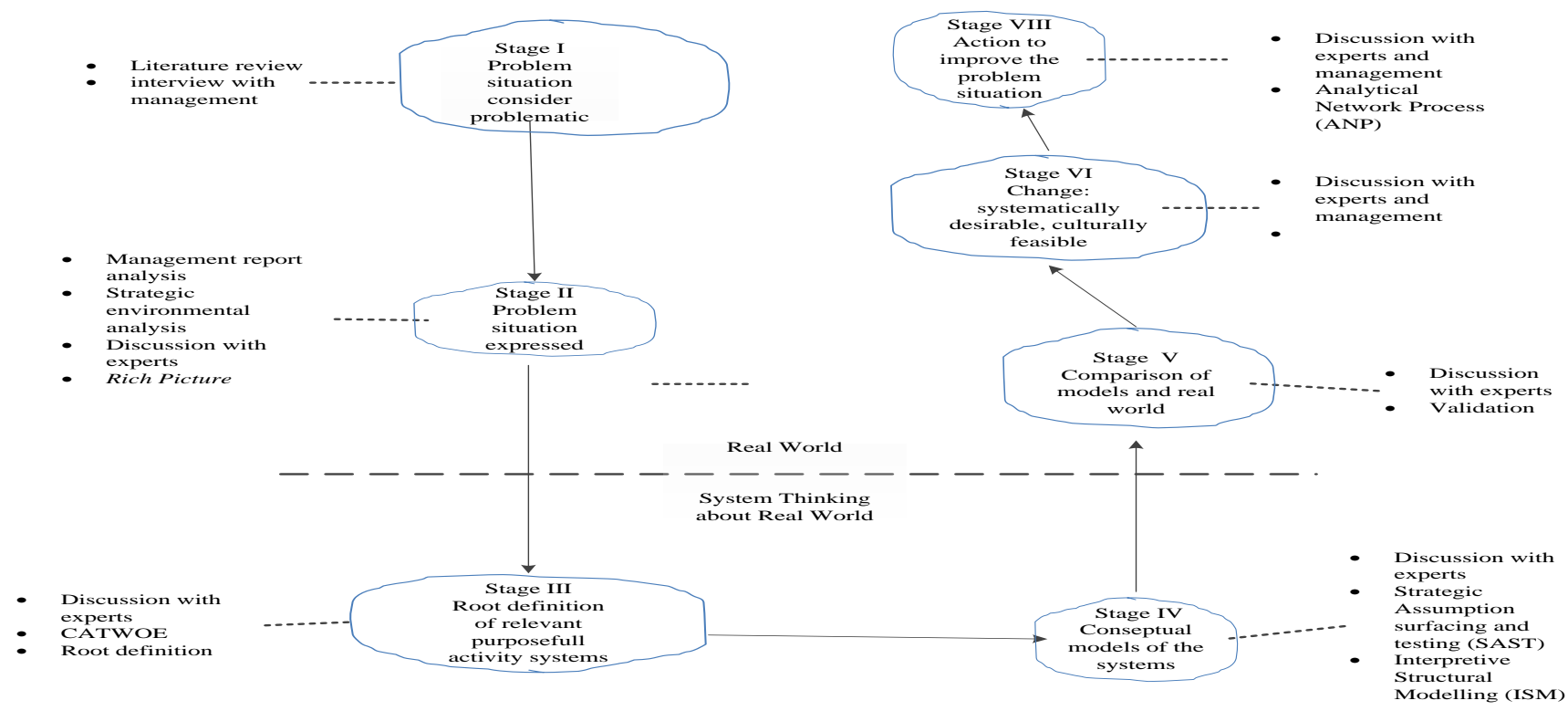

Figure 1: Research Method Process

The initial data of the study were obtained from literature studies, strategic environment analysis, management report analysis, questionnaires, interviews, and Focus Group Discussion/FGD and In-depth Interview (IDI) with experts to see the performance and the factors that influence ABC BUMN Holding's performance and its subsidiaries. In the fourth stage when preparing the model (purposive activity model), the SSM framework is combined with the SAST to find out the most important and most certain variables. Experts are asked to determine 41 Sub Variables from 9 variables that are considered to be the most important and certain. From the nine variables discussed, three variables related to government policy are institutional, competitive advantages, and governance. The other six variables are related to ABC BUMN Holding's strategies, namely sales, human resources, investment, productions, procurement of goods and services, and financing. SAST is one of the analytical techniques that emphasize the underlying assumptions of events compared to paying attention to the efficiency and the design of the system. Consequently, the SAST model uses free thinking system (unbound), or opposing (not always the same), and encompass multi-dimensional system. SAST is very helpful in opening up the strategic assumptions that underlie an implemented policy [29].

To find out which variable has the highest driver power and independence, an analysis is done with ISM. ISM is an established methodology to identify relationships between certain items, which determine a problem or issue as mentioned by [30]. [31] stated that ISM analyzes each element of the system and presents each relationship and hierarchy. Relationships and hierarchies are then presented in graphic. [32] proposed that The ISM method is developed to resolve complex and effective situations for planning and mapping relationships between various elements. ISM is an interactive learning process. According to [36], ISM analyzed 9 elements, namely: needs, constraints, possible changes, goals or objectives, targets or indicators, activities, actors, institutions or stakeholders, and affected segments. Experts agreed on five from the nine elements to be analyzed in this study, namely needs, constraints, objectives, possible changes, and actors. 


\section{DATA, SOURCE OF DATA, AND METHOD OF ANALYSIS}

This research is a combination of quantitative and qualitative method. Quantitative data is performance data before and after the holding is carried out and obtained from ABC BUMN Holding management reports. Qualitative data is data related to perceptions, interpretations and understanding of company performance as well as policies and strategies to improve it, collected from experts. Several methods are used to obtain comprehensive data on the performance of $\mathrm{ABC}$ BUMN Holding as well as policies and strategies to improve them. Methods entail literature reviews, management reports and holding proposals analysis, survey by distributing questionnaires and interviews with resource experts, FGD, and indepth interview. Data was obtained from 12 experts, consisting of 4 Directors and 2 staff of ABC BUMN Holding Director, 2 BUMN Directors outside ABC BUMN Holding, One Deputy of Government Internal Auditor of Indonesia (BPKP), Echelon II and Echelon III in BPKP who supervised ABC BUMN Holding, and one-person Chair of the Indonesian Governance Policy Committee. Quantitative data, obtained from management reports and holding proposals, were analyzed by descriptive statistics. Qualitative data, obtained from the analysis of questionnaire answers, interviews with experts, and strategic environmental analysis, were analyzed by SSM combined with SAST and ISM. The data obtained was further validated by experts and ABC BUMN management Holding.

\section{RESULT AND DISCUSSIONS}

\subsection{Stage I: Formulation of Problem Situation: Comparison Financial Performance Before and After Holding and Holding Proposals}

Descriptive statistics are used to compare financial performance before and after holding and holding proposal. Financial performance growth, namely sales, net income, assets, liabilities, equity, and financial ratios before and after the holding proposal are shown in Table 1. Financial ratios used in this study were Net Profit Margin (NPM), Debt to Equity Ratio (DER), Debt to Asset Ratio (DAR), Return on Assets (ROA), Return on Equity (ROE)

Table 1: Holding Proposal and ABC BUMN Holding Management Report

\begin{tabular}{|c|c|c|c|c|}
\hline Description & Unit & $\begin{array}{c}\text { Performance before } \\
\text { holding } \\
(\mathbf{2 0 0 9 - 2 0 1 3 )}\end{array}$ & $\begin{array}{c}\text { Performance after } \\
\text { holding } \\
(\text { 2014-2017) }\end{array}$ & $\begin{array}{c}\text { Holding } \\
\text { performance } \\
\text { prognosis } \\
(\mathbf{2 0 1 4 - 2 0 1 9 )}\end{array}$ \\
\hline Financial performance & & & & Growth \\
\hline Sales & $\%$ & 6.75 & (3.56) & 22.70 \\
\hline Net Profit & $\%$ & 2.52 & $(65.25)$ & 50.44 \\
\hline Asset & $\%$ & 17.96 & 23.60 & 12.20 \\
\hline Liability & $\%$ & 20.23 & 11.59 & 10.60 \\
\hline Equity & $\%$ & 13.42 & 51,61 & 15.31 \\
\hline Financial ratio & & & & Average \\
\hline NPM & $\%$ & 7.23 & $(1.25)$ & 11 \\
\hline DER & $\%$ & 187.18 & 139,23 & 191 \\
\hline DAR & $\%$ & 65.42 & 56.96 & 65.78 \\
\hline ROA & $\%$ & 5.34 & 0,22 & 12.38 \\
\hline ROE & $\%$ & 14.93 & $(0.56)$ & 35.2 \\
\hline
\end{tabular}

Source: ABC BUMN Holding Management Report and Holding Proposals

Table 1 shows that sales growth and net profit after holding are no better than before the holding and far from those targeted in the holding proposal. Development of assets, liabilities and equity is better than before holding due to asset revaluation and debt restructuring. NPM, ROA and ROE after the holding are worse than before the holding and far from the target of the holding proposal. DER and DAR are better because of asset revaluation.

The unfavorable performance of ABC BUMN Holding was caused by:

1. Institutional aspects: The law related to the BUMN holding continues to be a matter of discussion among the House of Representatives (DPR), and some DPR members have the desire to be involved in the selection of BUMN directors and commissioners. The establishment of ABC BUMN Holdings was not based on due diligence and was too optimistic. The holding company's role to provide added value to subsidiaries has not been analysed and should be part of the assessment of the holding company's performance that is reported to shareholders. Furthermore, we found that the assessment of the performance of plantation SOEs is apparently the same as manufacturing SOEs and there are still legal problems over the land that is controlled by ABC BUMN Holding.

2. Competitive advantages aspect: There is a massive and structured campaign that land use for oil palm causes deforestation and is not environmentally friendly. The government has made a bio ethanol bio diesel program, but the program has not met its targets. To improve the performance of ABC BUMN Holding, the government encouraged the 
revitalization of sugar mills by providing additional capital of Rp 3.5 trillion. This number is far from the amount needed for revitalization which reached 13 trillion. In addition, the cost of sugar production set by the government was lower than the actual cost. The performance of plantation companies also depends on the stability of the prices of plantation products. The prices of oil palm, sugar cane, rubber and tea commodities during the 2014-2018 periods tend to decrease, compared to prices before 2014.

3. Governance aspect: The selection of a President Director is based on a fit and proper test. However, the dismissal of the Board of Director has not been based on a clear management contract that includes Key Performance Indicators. Guidelines for subsidiary governance has not been made by the Ministry of BUMN.

4. Sales aspect: PT KPBN which was formed to auction the products of ABC BUMN has not been able to become a qualified plantation trader. BULOG apparently also has not played its role as a price stabilizer on the prices of plantation products, especially sugar.

5. HR Aspects: The number of HR is still too high, productivity is still low and there are still employees whose integrity still needs to be improved.

6. Investment Aspect: The Company is late in investing, so that of the 42 sugar mills owned by the company, 9 are not operational, and 21 of them are over 100 years old, so their productivity is low. Some palm oil mills are also often damaged and productivity is low. In addition, the company's investment focus is still upstream.

7. Production Aspect. Low production and productivity due to fertilization, maintenance and replanting that are not following the standards, as a result of financial difficulties.

8. Financing aspects: The focus of the holding is still on relatively large subsidiary debt restructuring, so the company's expansion is too late. The synergy of acquiring resources and utilizing resources between holding and subsidiaries also needs to be improved.

9. Procurement Aspects: In the context of providing goods and services, ABC BUMN Holding has built an integrated procurement system that still needs strong efforts so that this system can run effectively. In addition, there is still a delay in the procurement of fertilizers which has an impact on the delay in fertilization which affects production.

\subsection{Stage II: Determining the Problem Situation / Problem Situation Expressed (Rich Picture)}

This problematic situation is expresses in rich picture described in Figure 2.

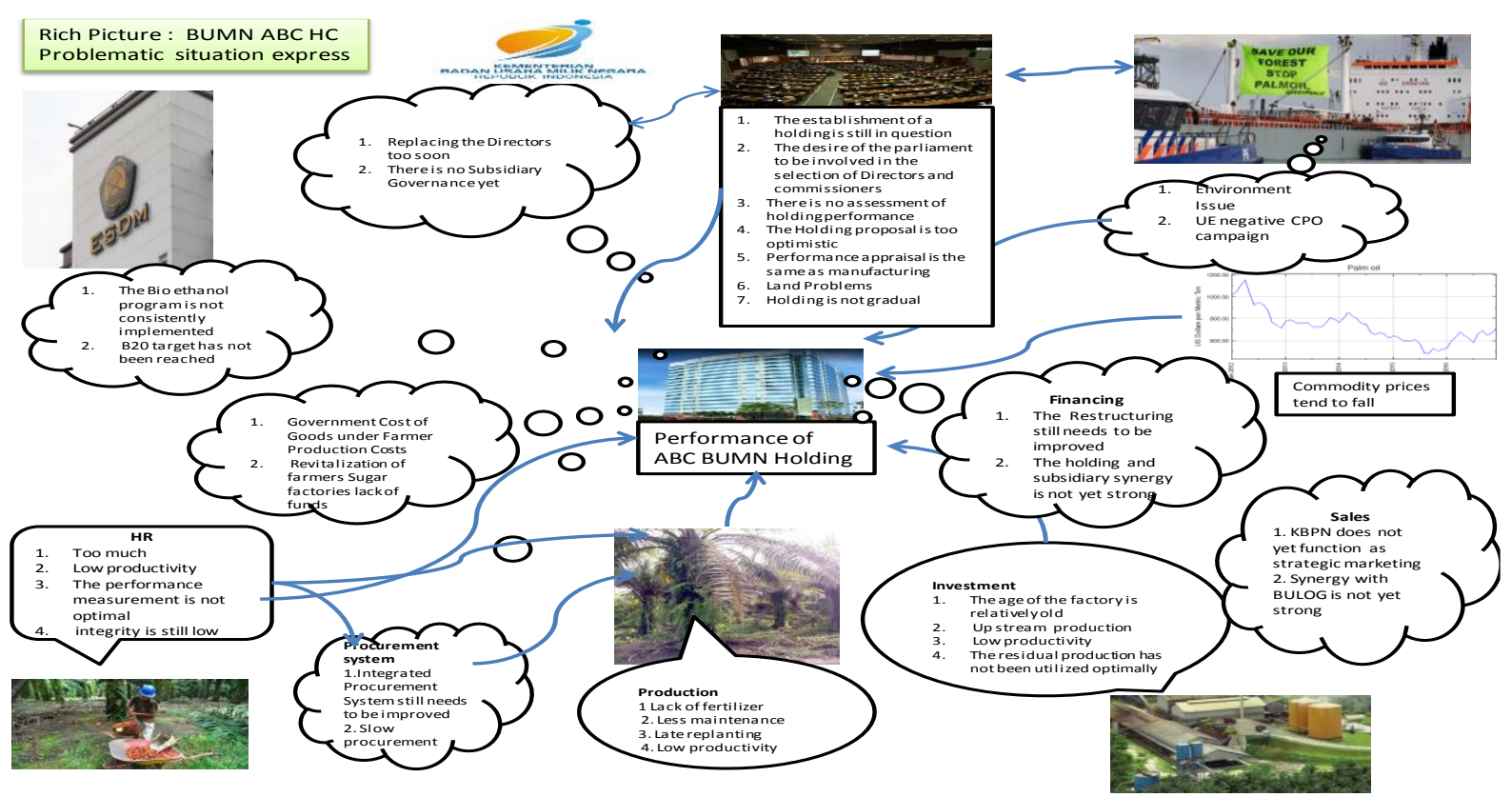

Figure 2 : Rich Picture

\subsection{Stage III: Determining Root Definition}

Root definition can be described using the PQR method by describing: Do "P" (what to do), with "Q" (how to do it) to reach "R " (why you should do it) [37]. 
Development of policies and strategies by perfecting institutional policies includes strengthening regulations of $B U M N$ s, increasing competitive advantage, and governance, as well as increasing product sales, human resources, investment, production, financing, and procurement of goods and services, thereby improving the performance of ABC BUMN Holding.

Root definition is then clarified by CATWOE analysis as shown in Table 2.

Table 2: CATWOE

C: Customers/Client

A: Actors

\section{T: Transformation}

W: World-view

O: Owners

E: Environmental Constraints
The model of policies and strategies that is being developed, aimed to improve ABC BUMN Holding performance.

House of Representative (DPR), Ministry of BUMN, Ministry of Energy and Mineral Resources (ESDM), Ministry of Industry, and Ministry of Trade as policy takers; ABC BUMN Holding Board of Directors as strategy executors; Board of Directors, Managers, and Employees of ABC BUMN Holding and its subsidiaries.

Policies and strategies model formulation that involves actors whose interest is to improve ABC BUMN Holding's overall performance.

Proposed policies and strategies model fulfills expectation and can be implemented by interested parties.

Ministry of BUMN; ABC BUMN Holding Board of Directors

Legal uncertainty in BUMN position, deforestation issues, lawsuits on land ownership issue, and the downward trend of plantation commodities prices.

\subsection{Stage IV: Creating Conceptual Policies and Strategies Model}

From the SAST and ISM analysis, we determined important and certain variables, and or has the highest driver power and independence that are : 1) definite legal rules related to BUMN, 2) plantation BUMN's land ownership certainty, 3) an intensive and integrated campaign by all stakeholders to prevent negative issues on CPO products, 4) a consistent program of bio ethanol and bio diesel implemented by the government 5) independent assessment of holding performance 5) synergy between holding company and subsidiaries in decision making, 6) strengthening subsidiaries governance, 7) increasing capability and integrity of human resources, 8) developing talent pool for innovation improvement, 9) development of downstream industries 10) rejuvenation of plantation production machines 11) IT development to integrate ABC BUMN's financial and operational data, 12) fertilization according to standard, 13) maintenance according to standard, 14) strengthening technological development for production and distribution efficiency, 15) acceleration of Integrated Procurement System implementation 16) special treatment for subsidiaries that continues to incur losses, 17) cooperation with other BUMNs in managing the company's operation, and 18) and the role of DPR, Ministry of BUMN, Ministry of Industry, Ministry of Trade, Ministry of Energy and Mineral Resources, and Directors of ABC BUMN Holding.

Based on Experts' discussion, SAST, and ISM analysis, a conceptual model is shown in Figure 5.

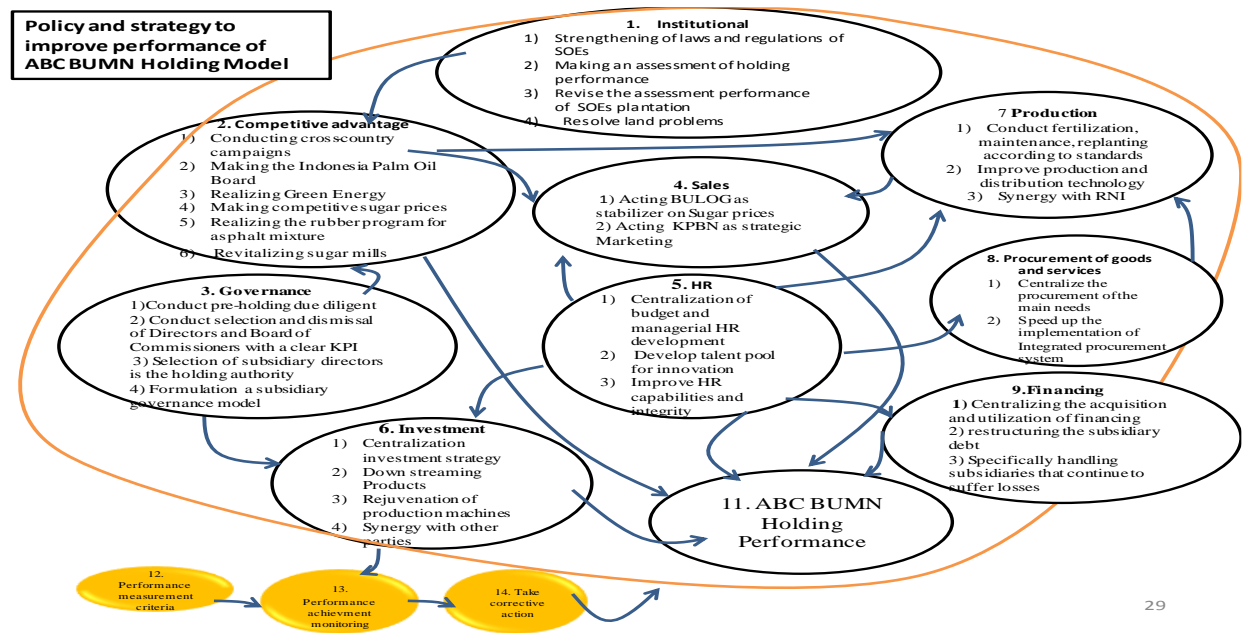

Figure 5: Conceptual models of policies and strategies to increase ABC BUMN holding performance

Figure 5 shows that the performance of government policies in institutions, strengthening competitive advantages, and governance will influence the strategies made by the company. One government policy will also influence other government policies. Likewise, the strategy that is built by the company will influence other strategies. Human resources play an important role in improving company performance due to its influence on other company strategies. 
6.5 Stage V, and Stage VI: Comparison Between Conceptual Model, Reality, and Possible Change That Can Be Done

Comparison between conceptual model and reality, and possible change that can be done are presented in Table 5

Table 3 : Comparison between Conceptual Model, Reality and Possible Change

\begin{tabular}{l} 
Conceptual model \\
\hline \multicolumn{1}{c}{ POLICIES } \\
- Strengthening the company based \\
on BUMN Law. \\
- Conducting a separate holding \\
performance assessment. \\
- Revising performance assessment \\
for ABC BUMN and its \\
subsidiaries \\
- Solving land ownership problems.
\end{tabular}

- Cooperation between countries to stabilize product prices and to tackle negative issues on plantation products.

- Forming Indonesia Palm Oil Board

- Realizing Green Energy.

- Establishing a competitive cost of goods sold for sugar.

- Establishing the use of rubber for road asphalt.

- Revitalizing sugar factories.

- Conducting pre-holding due diligence.

- Selecting and Terminating Directors and Commissioners using a clear key performance indicator.

- Formulating a subsidiaries governance model.

\section{STRATEGIES}

- Enacting KPBN as strategic marketing.

\section{Competitive advantages}

- Environmental issue and negative campaign of plantation product from the European Union.

- Insufficient investment fund to revitalize sugar factories.

- Inconsistent implementation of the bio ethanol program.

- Bio Diesel Program (B-20) Implementation does not meet its target.

- Plantation product prices face a downward trend.

\section{Governance}

- Holding proposal is too optimistic

- Holding establishment is not done gradually.

- Director changes frequently and the criteria for appointment and dismissal are unclear.

- No subsidiaries governance guidelines.
Possible changes

- An intensive discussion between the government and the House of Representative (DPR) on strengthening the company based on BUMN Law.

- Including Holding performance assessment in management report.

- Conducting a study and deciding performance assessment for plantation companies.

- Coordinating with other ministries to solve ABC BUMN Holding and its subsidiaries land ownership problems.

- Merging RNI Plantation subsidiaries company with $\mathrm{ABC}$ BUMN Holding.

- Forming strategic holding.

- Cooperation across ministries, APKASI, and across countries that produces CPO to tackle negative issues on plantation products and to stabilize plantation product prices.

- The government established targets for the bio ethanol and the bio diesel programs that are agreed upon by all the parties involved.

- Continuing the revitalization of sugar factories.

- Perfecting sugar trading system.

- Include the use of rubber as road asphalt as a clause in road procurement contracts.

- Establishing a due diligence guideline in terms of BUMN holding execution.

- Establishing guidelines and monitor the achievement of key performance indicator that is quantifiable for Directors and Commissioners.

- Formulating guidelines in creating subsidiaries governance. 


\begin{tabular}{|c|c|c|}
\hline Conceptual model & Reality & Possible changes \\
\hline $\begin{array}{l}\text { - Centralizing the budget and the } \\
\text { development managerial human } \\
\text { resources. } \\
\text { - Developing talent pool to } \\
\text { strengthen innovation. } \\
\text { - Increasing the capability and } \\
\text { integrity of human resources. } \\
\text { - Strengthening cooperation } \\
\text { between the holding company and } \\
\text { subsidiaries (eliminating silo). }\end{array}$ & 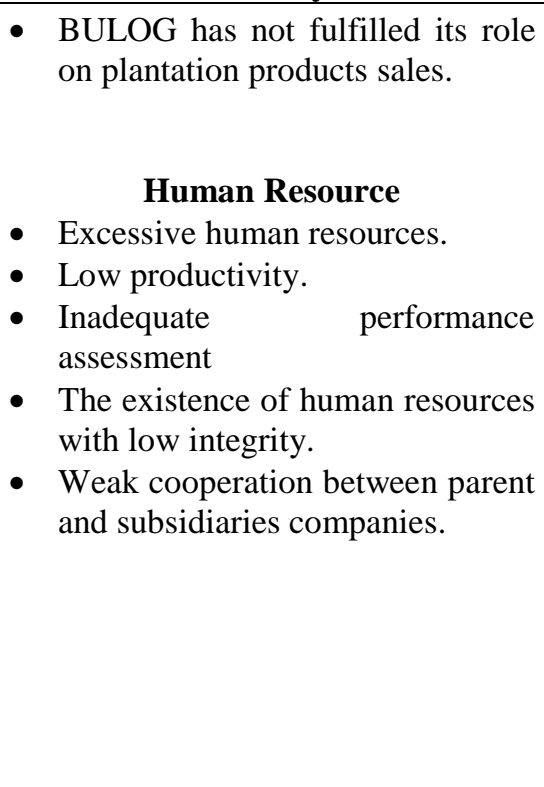 & $\begin{array}{l}\text { BULOG for State Plantation } \\
\text { product sales. } \\
\text { - Suggesting the appointment of } \\
\text { BULOG as sugar price stabilizer. } \\
\text { - Utilization of subsidiary budget } \\
\text { for centralized managerial human } \\
\text { resources development. } \\
\text { - Increasing the capability and } \\
\text { integrity of ABC BUMN Holding } \\
\text { human resources and its } \\
\text { subsidiaries. } \\
\text { - Rationalizing ABC BUMN } \\
\text { Holding human resources and it } \\
\text { subsidiaries } \\
\text { Using talent pool to strengthen } \\
\text { innovation. } \\
\text { Increasing synergy between parent } \\
\text { and subsidiaries. }\end{array}$ \\
\hline $\begin{array}{l}\text { - Centralizing investment strategy. } \\
\text { - Developing downstream industry } \\
\text { - Investment cooperation with third } \\
\text { parties. } \\
\text { - Rejuvenating plantation product } \\
\text { machinery. } \\
\text { - Technological development to } \\
\text { integrate financial and operational } \\
\text { data. }\end{array}$ & $\begin{array}{l}\text { Investment } \\
\text { - Upstream investment. } \\
\text { - Lack of investment strategy } \\
\text { integration. } \\
\text { - Old machineries. }\end{array}$ & $\begin{array}{l}\text { - Conducting a study to invest on } \\
\text { downstream products in the form } \\
\text { of plantation products derivatives. } \\
\text { - Appointing one subsidiary as a } \\
\text { caretaker for downstream } \\
\text { industry. } \\
\text { - Synergy between strategy and } \\
\text { investment activity. } \\
\text { - Revitalization of aged plantation } \\
\text { production machinery. } \\
\text { - Technological development for } \\
\text { financial and operational data } \\
\text { integration. }\end{array}$ \\
\hline $\begin{array}{l}\text { - Fertilizing, maintaining, and } \\
\text { replanting in accordance with } \\
\text { standard. } \\
\text { Technological development to } \\
\text { increase production and } \\
\text { distribution efficiency. } \\
\text { - Synergy between ABC BUMN } \\
\text { Holding and RNI. } \\
\text { - Taking advantage of excess in } \\
\text { electric capacity. }\end{array}$ & $\begin{array}{l}\text { Production } \\
\text { - Unstandardized fertilizing, } \\
\text { maintenance, and replanting. } \\
\text { - Sugar factory's excess in electric } \\
\text { capacity is unused. } \\
\text { - Low productivity. }\end{array}$ & $\begin{array}{l}\text { - Establishing targets in fertilizing, } \\
\text { maintenance, and replanting in } \\
\text { accordance with standard. } \\
\text { - Establishing a cooperation } \\
\text { contract to utilize resources with } \\
\text { PT RNI. } \\
\text { - Coordinating with Ministry of } \\
\text { Energy and Mineral Resources } \\
\text { (ESDM) and the State Electric } \\
\text { Company (PLN) to utilize the } \\
\text { excess electrical capacity of sugar } \\
\text { factories. } \\
\text { Developing technologies to } \\
\text { increase production and } \\
\text { distribution efficiency. }\end{array}$ \\
\hline $\begin{array}{l}\text { - Accelerating IPS implementation. } \\
\text { - Centralizing the procurement of } \\
\text { primary necessities for } \\
\text { production. }\end{array}$ & $\begin{array}{l}\text { Procurement of Goods and } \\
\text { Services } \\
\text { - Integrated Procurement System is } \\
\text { ineffective. } \\
\text { - Procurements are delayed. } \\
\text { - Not all procurements are } \\
\text { centralized. }\end{array}$ & $\begin{array}{l}\text { - Accelerating Integrated } \\
\text { Procurement } \\
\text { implementation. } \\
\text { - } \begin{array}{l}\text { Procurements in accordance with } \\
\text { schedule. }\end{array}\end{array}$ \\
\hline
\end{tabular}




\begin{tabular}{|c|c|c|}
\hline Conceptual model & Reality & Possible changes \\
\hline $\begin{array}{l}\text { - Centralizing financing acquisition } \\
\text { and utilization. } \\
\text { - Restructuring subsidiaries' debts. } \\
\text { - Special treatment for subsidiaries } \\
\text { that continues to incur losses. }\end{array}$ & $\begin{array}{l}\text { Financing } \\
\text { - Not all financing is centralized. } \\
\text { - Substantial debts incur by } \\
\text { subsidiaries. } \\
\text { - Nonexistent treatment for } \\
\text { subsidiaries that continues to incur } \\
\text { losses. }\end{array}$ & $\begin{array}{l}\text { - Centralizing the procurement of } \\
\text { primary necessities for production } \\
\text { implementation. } \\
\text { - Restructuring subsidiaries' debts. } \\
\text { - Regrouping and Merging } \\
\text { subsidiaries that continues to incur } \\
\text { losses with subsidiaries that have } \\
\text { great performance. } \\
\text { - Dissolution of a subsidiary that } \\
\text { continues to suffer losses. }\end{array}$ \\
\hline
\end{tabular}

\subsection{Managerial Implications}

From the SSM analysis which was later strengthened by SAST and ISM it was found that the performance improvement of ABC BUMN Holding was also influenced by government policies. The government should conduct intense discussions with the House of Representatives (DPR) to strengthen the company in accordance with BUMN Law, include performance achievements of holding companies in management reports, conduct studies and decide performance assessment for plantation companies, conduct cross-institutional and cross-country synergies to counteract negative issues on plantation products, continue to pursue bio ethanol and bio diesel programs, and encourage the making of subsidiaries governance. ABC BUMN Holding should cooperate with RNI, KPBN and BULOG in selling plantation products, improve human resources capabilities and integrity, improve cooperation between parent company and subsidiaries, increase investment in downstream industries, formulate fertilizing, maintaining, and replanting targets according to standards, develope technologies to increase production and distribution efficiency, and restructuring subsidiaries' debt.

\section{CONCLUSIONS AND SUGGESTIONS}

Conclusions: Based on the analysis of strategic environment and management reports that is assisted by SSM and strengthened by SAST and ISM, it was concluded that the poor performance of ABC BUMN Holding was partly due to the formation of a holding that was not preceded by due diligence, financial difficulties that had an impact on fertilizing, maintaining, and replanting that are not in accordance with standards, human resources with low capability and integrity, as well as a downward trend in plantation commodity prices.

Suggestions: In making policies and strategies, the government and ABC BUMN Holding should pay attention the important and certain variables that have high leverage, among others: definite legal rules related to BUMN, tackling negative issues on plantation products, synergy between holding company and subsidiaries in decision making, independent assessment of holding performance, strengthening subsidiaries governance, increasing capability and integrity of human resources, strengthening technological development for production and distribution efficiency, developing talentpool for innovation improvement, and synergy between DPR, Ministry of BUMN, Ministry of Industry, Ministry of Trade, Ministry of Energy and Mineral Resources, and Directors of ABC BUMN Holding.

\section{REFERENCES}

[1] Giuseppe, Grossi, Ulf P, Marie-ST, "Corporate Governance and Accountability of State-Owned Enterprises: Relevance for Science and Society and Interdisciplinary Research Perspectives". International Journal of Public Sector Management, vol. 28, no. 4, pp.274-285, 2015.

[2] Peter D, Tamyko Y, Daniel S, "Corporate governance of state-owned enterprises: a systematic analysis of empirical literature", International Journal of Public Sector Management, vol. 3, no. 5, pp.447-466, 2017.

[3] Ines W, "Disciplines on State-Owned Enterprises in International Economic Law: Are We Moving in the Right Direction?", Journal of International Economic Law, vol. 19, no. 3, pp.657-680, 2016.

[4] [OECD] Organization for Economic Cooperation and Development, State-owned Enterprise Governance Reform, An Inventory of Recent Change, pp.1-54, 2011.

[5] Law Number 19/2003 on State Owned Enterprise (BUMN).

[6] Bozec R, "Boards of directors, market discipline and firm performance", Journal of Business Finance and Accounting, pp.1921-1960, 2005.

[7] Magang TI, Magang VG, "Corporate Governance and Compliance in Botswana: Issues and Challenges", Journal of Research in Business, Economics and Management (JRBEM), vol. 7 no. 1, pp.1041-1061, 2016.

[8] Abeng T, Reformasi BUMN, dalam BUMN Indonesia: Isu, Kebijakan dan Strategi. Jakarta (ID). Alex Media Komputindo, 2005.

[9] Budi A, Political cost and BUMN, Jakarta, Indonesia: UI Press, 2012.

[10] Assagaf A, Ali H, "Determinant of financial performance of state-owned enterprices with government subsidy as moderator", International Journal of Economics and Financial Issues, vol. 7, no. 4, pp.330-342, 2017. 
[11] Kočenda E, Hanousek J, "State Ownership and Control in the Czech Republic”, CESifo Working Paper Series No. 2801, vol. 45, no. 3, pp.157-191, 2012a.

[12] Ki-An P, Chan-Kyung K, Joon-Young L, "Strategic Investment Policy in a Growing Market: Factors for the Management Strategy of Korean Firms in China", Asian Business \& Management, vol. 1, pp.59-77, 2002.

[13] Pranoto T, Wakaliwe W, Restrukturisasi BUMN Menjadi Holding Company [BUMN Restructuring Becomes a Holding Company], Lembaga Manajemen UI, Jakarta (ID): UI Press, 2013.

[14] Ficbauer D, Režňakova M, "Holding Company and Its Performance”, Acta Universitatis Agriculturae et Silviculturae Mendelianae Brunensis, vol. 62, no. 2, pp.329-337, 2014.

[15] Karas M, Režňakova M, "Bankruptcy Prediction Model of Industrial Enterprises in the Czech Republic", International Journal of Mathematical Models and Methods in Applied Sciences, vol. 7, no. 5, pp.519-531, ISSN 1998-0140.

[16] Cartwright S, Schoenberg R, "Thirty years of mergers and acquisitions research: Recent advances and future opportunities", British Journal of Management, vol. 17, pp.1467-8551, 2006.

[17] Wong, Simon CY, Key Elements to Improve Corporate Governance, Mc Kinsey Publication, 2006.

[18] Mattlin M, "Chinese strategic state-owned enterprises and ownership control. Brussels Institute of contemporary china studies", Asia Paper, vol. 4, no. 6, pp.1-28, 2007.

[19] Curtis JM, Wentong Z, "Beyond Ownership: State capitalism and the Chinese firm”, The George town law journal, vol. 103, no. 665, pp.667-772, 2015.

[20] Daniel S, "Competition policy and comparative corporate governance of state-owned enterprises”, Brigham young university law review, vol. 210, no. 02, pp.1715-1811, 2009.

[21] Nickols F, Strategy: Definition and Meaning, pp.1-8 [Internet]. [cited January 10, 2017] available from: http: //www. nickols.us/strategy_definition, 2015.

[22] Tregoe B, Zimmerman JW, Top Management Strategy, Simon \& Schuster, New York, 1980.

[23] Campbell A, Whitehead, J, Alexander M, Goold M, Strategy for the Corporate Level. John Wiley \& Sons, Ltd, 2014.

[24] Cross OD, "Effect of Organizational Change on Employee Job Performance", Asian Journal of Business and Management, vol. 7, no. 4, pp.2321-2802, 2019.

[25] Checkland P, Poulter J, Learning For Action: A Short Definitive Account of Soft Systems Methodology, and its use for Practitioners, Teachers and Students. John Wiley \& Son, Ltd., 1990.

[26] Wicaksono SE, Marimin, Arief D, Imam TP, "Development of the business model of stated-owned bank to support financial inclusion in Indonesia", Asian Journal of Social Science, vol. 7, no. 2, pp.168-179, 2019, ISSN:2321-0893.

[27] Marimin, Maghfiroh M, Aplikasi Tehnik Pengambilan Keputusan Dalam Manajemen Rantai Pasok [Application of Decision Making Techniques in Supply Chain Management], Bogor (ID): IPB Press, 2010.

[28] Hardjosoekarto S, Soft System Methodology (Metode Serba Sistem Lunak), Jakarta, Indonesia: UI Press, 2012.

[29] Flood RL, Jackson MC, Creative problem solving: Total systems intervention, Wiley Chichester, New York US, 1991.

[30] Attri R, Dev N, Sharma V, "Interpretive structural modeling (ISM) approach: an overview”, Research Journal of Management Science, vol. 2, no. 2, pp.1-8, 2013.

[31] Warfield J, Developing Interconnection Matrices in Structural Modelling, IEEE Transactions on Systems, Man and Cybernetics, vol. 4, no. 1, pp.51-81, 1974. Doi:10.1109/TSMC.1974.5408523.1974

[32] Verma RK, "Implementation of interpretive structural model of topsis manufacturing industries for supplier selection", Industrial Engineering Letter, vol. 4, no. 5, pp.1-9, 2014.

[33] Sage A, Interpretive Structural Modelling: Methodology for Large-scale Systems, Mc Graw-Hill, New York, 1997.

[34] Raj T, Shankar R, Suhaib M, “An ISM approach for modeling the enablers of flexible manufacturing system: The case for India”, International Journal of Production Research, vol. 46, no. 24, pp.1-30, 2007.

[35] Raj T, Attri R, "Identification and modelling of barriers in the implementation of TQM", International Journal of Productivity and Quality Management, vol. 28, no. 2, pp.153-179, 2011.

[36] Saxena JP, Sushil, Prat V, "Hierarchy and classification of program plan elements using interpretive structural modeling: A Case Study of Energy Conservation in the Indian Cement Industry”, System Practice, vol. 5, no. 2, pp.651-670, 1992.

[37] Checkland P, Scholes J, Soft System Methodology in action, John Wiley \& Son, 1td, England, 1998. 